\title{
渑池涧河生态综合治理之景观设计
}

\author{
员百江 \\ 三门峡市黄河公园管理处 \\ DOI:10.32629/eep.v3i6.864
}

\begin{abstract}
[摘 要] 涧河位于渑池县城南部, 北临城市, 西与涧河一二期相连,东至S247省道,总面积54.31公顷, 改造 总长度 $4.58 \mathrm{~km}$ 。渑池涧河环境综合整治不仅可以提高渑池县城市防洪安全、增强抵抗洪涝灾害风险的 能力, 而且改善了沿岸滨水环境, 为市民提供了滨水休闲娱乐空间, 提升居民生活水平, 并可以形成具有渑 池县特色的城市滨水景观带, 提升了城市品位, 体现了城市特色, 打造出城市名片的新形象。同时将中水 处理厂处理后达标的中水资源化为利用, 作为河道补水的水源, 并用来满足沿线道路冲洗、市政公园绿化 用水、市政环保及工业园区用水, 不仅解决了涧河缺水的问题, 还优化了水资源配置方案, 缓解了渑池县 水资源短缺的压力,工程意义重大。
\end{abstract}

[关键词] 渑池涧河; 规划设计; 生态景观

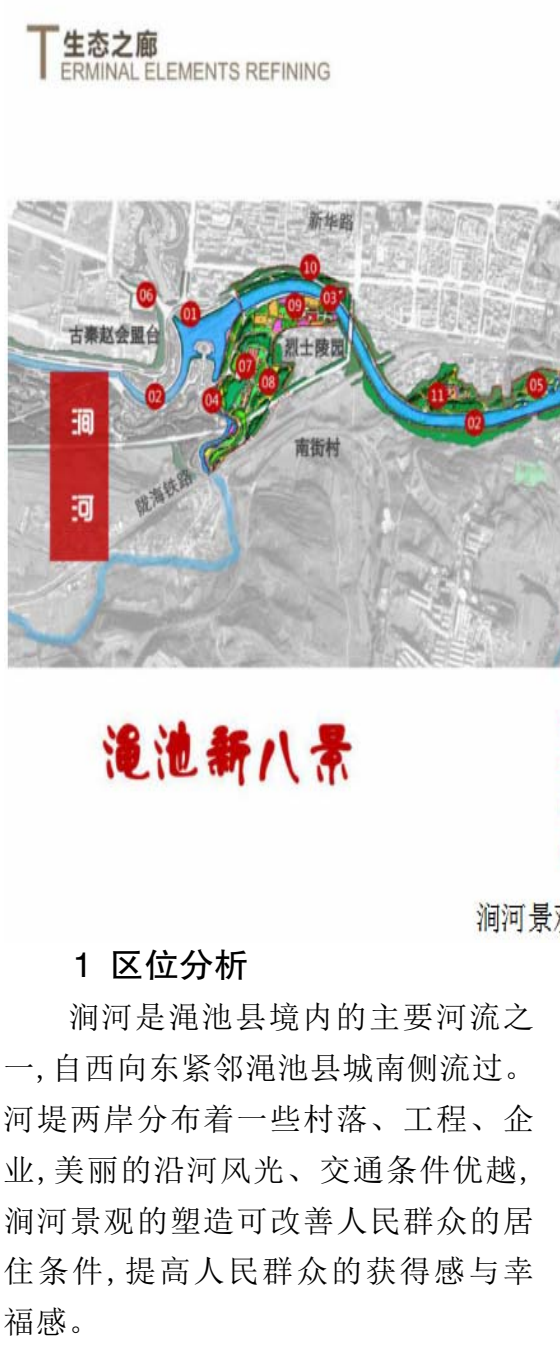

构建清水绿岸的生态水系。

\section{2 劣势分析}

渑池涧河河道为下切型河流, 河道 岸坡受水流冲蚀明显, 部分河段河道弯 曲, 岸坡受水流顶冲。部分岸坡整体稳定 性较差, 水利河道与景观设计, 生态修复 需要紧密配合, 相互协调。

\section{3 设计原则}

3. 1 生态修复与保护优先原则

以提高植物多样性和水质环境保护 为基础, 采用有利于保护原有生态环境 的措施, 尽可能的保护原有地形地貌以 及植被, 对生境的改造控制在最小的程 度和范围, 营造适宜生物多样性发展的 环境空间, 防止外来物种的入侵, 为鸟 类、鱼类等各种湿地生物的生存提供最 大和最佳的生息空间。

3. 2 坚持因地制宜, 可持续发展的 原则

从 “因水而生、因水而兴、因水而 美” 的理念出发, 结合项目所在地气候特 征, 及项目不同功能区施工的特定环境 条件, 本着 “适地适树、适地适草” 的原 则, 以乡土植物为主, 适当引进一些优良 植物; 在发挥林草防护和观赏等综合功 能的前提下, 做到即防风、防噪、又美观 的效果, 最终建成“城在园中, 水在城中, 楼在绿中, 人在景中”可持续发展的城市 态、水环境、水灾害领域存在的问题, 
生态廊道。

3. 3 适度开发与合理利用原则

项目基调为公益性, 适量少的考虑 运营, 投入为主, 产出为辅。

\section{4 景观风貌策划}

4. 1 设计定位

将渾池润河景观打造成淹池人们的 后花园, 扩大园林景观效果, 让沿岸的工 农业与环境形成共赢, 创造吸引外资的 投资平台, 充分带动经济的发展。

\section{2 景观情景}

景观情景空间的人为要素与当地人 们的生活方式相协调, 达到人与景的互 动融合, 在整个风景区的设计中, 适当增 加当地文化特色的情景雕塑、水景节点, 来提升小空间的景观效果, 渲染大场景, 烘托氛围。

\section{3 景观功能}

涧河主要景观节点按照空间特性分 为三个地块: 生态公园 (原涧河生态公园 以东包含橡胶坝下游湿地, 烈士陵园以 西区域, 总面积 $150000 \mathrm{~m}^{2}$ ); 中部区域(渑 杨铁路与润河交汇处以东, 小寨沟与涧 河交汇处以西区域, 位于润河北岸, 总面 积 $55000 \mathrm{~m}^{2}$ ); 吕祖圣泉 (包含现有吕祖山 景区以及吕祖山泉周边, 不含吕祖山为 总面积 $\left.16000 \mathrm{~m}^{2}\right)$

\section{4 景观结构}

结合淹池县 “一河两沟” 现状及分 布情况, 充分体现因地制宜, 合理开发, 总体上形成 “一心三带六区多点” 的规 划布局结构。

一心: 涧河生态公园为一心, 是整个 “一河两沟”的景观核心部位, 地理位置 优越, 景观效果显著。

三带：涧河生态带, 羊河沟生态 带、小寨沟生态带。以改造后的“一 河两沟” 水利工程为契机, 沿河道两岸 利用可利用的有限土地, 各自整合成 为景观带。

六区：分别为浪漫花谷, 中心公园, 动力花园, 湿地探幽, 吕祖圣泉, 陶艺 文化。

多点：指的是沿 “一河两沟” 两岸 的各广场、游园、运动场所、湿地营造 等多点通过河道连接形成了一个大的生

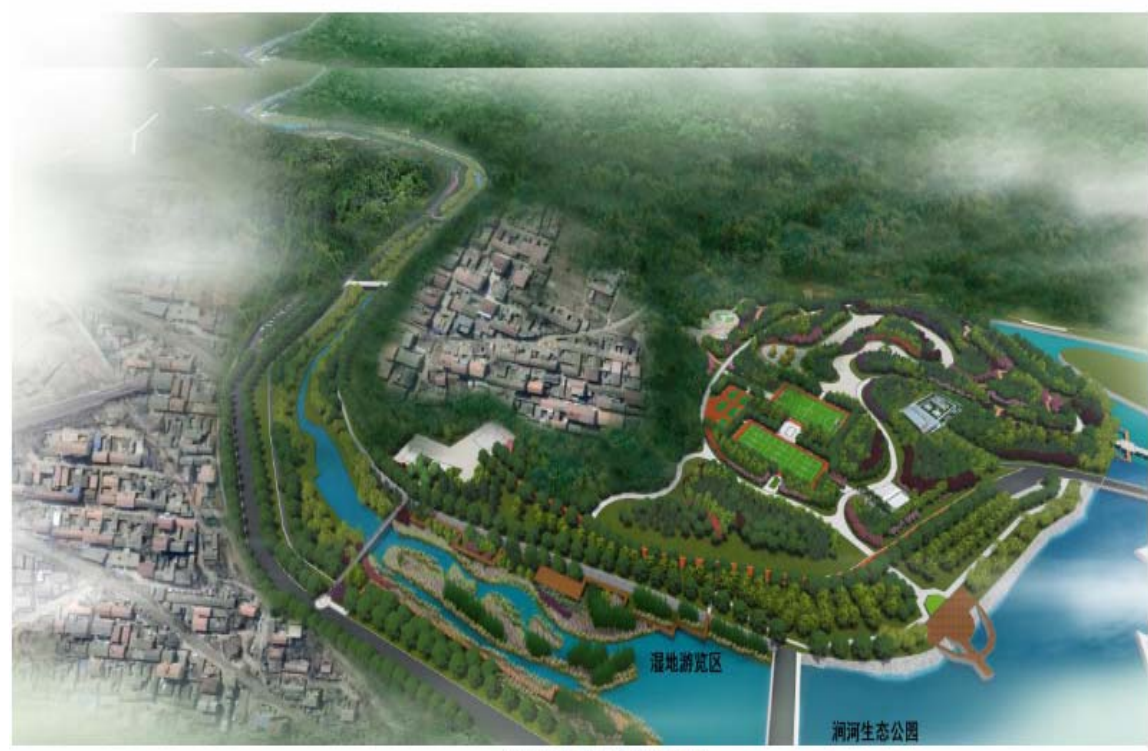

洵河景观鸟瞰图

态景区。

\section{5 涧河道路体系}

采用适当的绿色交通路线, 设计适 宜人们穿梭的绿色空间, 增加沿河景观 品质。设计中采用多元化、多层面的手 法。巧妙的结合周边景观效果, 保证绿色 交通的完整性和连贯性。

\section{6 植物配置}

\section{1 种植原则}

充分考虑园林植物季节变化, 形成 三季有花, 四季常绿的景观效果。常青和 落叶, 乔木和灌木, 速生和慢生相结合的 原则。乔木拉开骨架, 灌木和球类补充空 间。结合本地绿化建设需要, 注重常绿 与落叶、阔叶与针叶、乔木与灌木, 重点 美化树种与速生普遍绿化树种相结合, 乔木、灌木和草坪的比例推荐为 $6: 3: 1$ 的比例, 加强高大乔木的比例, 多用银 杏、合欢、法桐等观赏性和实用性都比 较强的树种。

\section{2 种植方式}

行列式种植方式: 相邻两株植物之 间的间距及每株植物与道路之间的间距 都应相等, 不可小于 $4 \mathrm{~m}$ 。种植要求: 依配 置要求种植, 若遇到地管道等阻碍物时, 适当调整间距; 苗木的分枝点高度必须 一致 (误差在 $20 \mathrm{~cm}$ 以内), 自然高度应基 本一致, 若出现不一致时, 应将较高苗木 种植在树列中间位置, 使林冠线呈平滑 的拱形, 杜绝形成凹形。
自然搭配种植方式: 种植要求: 从 植或群式种植的乔灌木, 同种或不同种 苗木都应高低错落, 充分体现自然生长 的特点。

花灌木、地被植物的分层种植方 式: 花灌木边缘轮廓线上的种植密度 应大于规定密度, 平面线形应流畅, 外 缘成弧形, 高低层次应分明, 且于周边 点种植物高度差不少于 $300 \mathrm{~mm}$ 。修边、 收边、人工式种植要求边界清楚、无 空缺、生长均匀, 自然式种植相互入侵 合理, 要求主次分区明显, 入界合理, 合于自然。

地被植物的种植要求: 应按品字形 种植, 确保覆盖地表, 且植物带边缘轮廓 线上的种植密度应大于规定密度, 以利 于形成流畅的边线, 同时轮廓外缘在立 面上应成弧形, 使相邻两种植物的过度 自然。

\section{7 坚向设计}

7. 1 景观互动

景观情景空间的人为要素与当地人 们的生活方式相协调, 达到人与景的互 动融合, 在整个风景区的设计中, 适当增 加当地文化特色的情景雕塑、水景节点, 来提升小空间的景观效果, 渲染大场景, 烘托氛围。

\section{2 漫步空间}

穿林而过, 硬景建设与绿化环境 相融合, 成为市民晨练, 黄昏散步的最 
佳选择, 为满足游人的休㮩要求, 设计 大的节点广场, 适当增添一些成品坐 具, 更能体现人性化设计环境所带给 人们的感受。

\section{3 突出人本主题}

强调以人为本, 从人的休咊、观景、 交往等功能需求出发, 合理设置休闲、 步行、观景、集聚、运动等空间, 充分 考虑景观设施细节, 营造现代化人性绿 色环境。

\section{4 塑造绿色生态形象}

以生态学原理为指导构建绿地系 统。根据植物的共生、多样性以及竞争 效应, 因地制宜布置乔、灌木、草本、 藤本、水生植物, 使之相互协调, 营造一 个人与自然和谐共生、良性互动的生态 环境。

\section{8 水土流失现状及防治情况}

8. 1 防治目标

新增的水土流失量得以及时有效的 控制、水土流失强度恢复到工程前水平 并有所改善、植被率不低于现状水平、 生态环境有所改善。

\section{2 防治责任范围}

项目建设区是指开发建设单位的征
地范围、租地范围和土地使用管辖范围。 主要包括:

(1)主体工程建设区。

(2)临时道路建设区。

(3)施工生产生活占地。

(4)取土场建设区。

(5)弃渣场建设区。结合本工程, 弃渣 全部运至渑池县垃圾填埋场, 本次用地 只考虑前四项。

8. 3 防治措施布设原则

坚持 “因地制宜, 因害设防” 的设计 原则。结合项目区水土流失特点, 因地制 宜、因害设防, 采用工程、植物、临时措 施相结合, 构成完整的水土保持防治体 系, 同时认真分析主体工程具有水保功 能的措施布局, 避免措施重复造成投资 重复计列。

8. 4坚持 “点式工程和线性工程” 相 结合的设计原则。

本项目施工既有点式工程又有线性 工程, 线性工程主要有主体工程及临时 道路工程; 点式工程中包括弃渣场区和 施工生产生活区, 但扰动强度和施工特 点却不尽相同。因此, 必须结合不同区域 的扰动特点, 科学划分防治分区, 并针对
各防治分区的扰动特点布设水土流失综 合防治措施。

\section{9 结束语}

综上所述, 润河景观对于渑池的发 展影响是深远的、它不仅是市民生活的 重要组成部分, 更是游客认识渑池的窗 口, 从润河的角度观看淹池的展示面, 塑 造城市形像是淹池发展的方向和需要, 淹池涧河景观所呈现的效果, 极大地影 响渑池整体印象, 因此, 涧河景观设计要 努力凸显渑池的内涵和品位, 满足人们 的精神文化和生活需求。

\section{[参考文献]}

[1].城市湿地公园规划设计导则 (试行)[J]. 凤景园林,2006(01):32-33.

[2].国家城市湿地公园管理办法(试 行)[J]. 北京规划建设,2005(2):196-197.

[3]孔彦鸿, 桂萍, 董柯.《生态城市 总体规划导则》编制研究 [J]. 建设科 技,2011(15):34-38.

\section{作者简介:}

员百江 (1975--), 男, 汉族, 河南省 三门峡市人, 本科学历, 高级工程师, 从 事园林景观设计、绿地养护管理方面 研究。 